\title{
Examining Career and Academic Outcome Expectations of Turkish High School Students
}

\author{
Gürcan Şeker (Corresponding author) \\ Department of Education Sciences, Niğde Ömer Halisdemir University \\ Merkez Yerleşke, Niğde, 51240, Turkey \\ Tel: 90-388-2254377Ｅ-mail: gurcanseker@ohu.edu.tr
}

$\begin{array}{lc}\text { Received: August 15, } 2020 & \text { Accepted: September 16, } 2020 \quad \text { Published: October 3, } 2020 \\ \text { doi:10.5296/jei.v6i2.17532 } & \text { URL: https://doi.org/10.5296/jei.v6i2.17532 }\end{array}$

\begin{abstract}
This study aimed to examine career and academic outcome expectations of high school students. Data of the research designed in the survey model were collected from 695 students attending ninth to twelfth grades of high schools that offer academic and vocational education in city center of Niğde in the Central Anatolian Region of Turkey in the academic year of $2018-2019.56 \%$ of the participants are female and $44 \%$ are male. The measures used in the research are academic outcome (5 items) and career outcome (4 items) expectation subscales of the Career Outcome Expectations and Exploration Intentions Scale developed by Betz and Voyten (1997) and adapted into Turkish language by Büyükgöze-Kavas (2011) and the Personal Information Form developed by the researcher. Independent groups t-test and one-way ANOVA analysis techniques were utilized in data analysis. It was found in the data analysis that high school students' scores of career and academic outcome expectations differed significantly by gender, type of school, and grade level. While girls were found to have higher mean scores of career and academic outcome expectations than boys, the students of Anatolian High School that provides academic education had higher mean scores of career and academic outcome expectations than the vocational high school students. Furthermore, ninth-grade students were found to have higher mean scores of career and academic outcome expectations than other grade levels.
\end{abstract}

Keywords: Career outcome expectations, Academic outcome expectations, Turkish high school students

\section{Introduction}

Among the theories trying to explain the career development process, Social Cognitive Career Theory based on Bandura's social cognitive theory focuses on individual's belief that 
they can achieve something (Sharf, 2014). Approaches and methods brought about by the Social Cognitive Career Theory can be efficiently utilized by individuals to increase their self-efficacy expectations in their interests, develop realistic and positive outcome expectations, set their own goals, expand their vocational interests, improve their decision-making skills, and improve their career planning and research behaviors (Swanson \& Fouad, 1999).

Social Cognitive Career Theory importantly draws attention to three interrelated variables which help individuals regulate their career behaviors: self-efficacy expectation, outcome expectation and personal goals (Lent \& Brown, 1996). Children and adolescents develop efficacy and outcome expectations about different areas of duty and behavior when improving their skills and personal performances by receiving positive or negative feedbacks about their performances in several activities (Lent, 2005).

According to Bandura (1986), self-efficacy and outcome expectations are concepts that should be discriminated from each other. Outcome expectation is one's expectancy about the outcome of a behavior that they performed. Self-efficacy expectancy is one's belief that they can exhibit behaviors required for them to achieve an outcome. An individual can successfully perform a task but may not receive the satisfaction such as reward, appreciation, etc. they expect. Outcome expectations increase individual's motivation to deliver the task during the performance of the behavior. That is to say, it supports behavior-oriented action, which is generally managed by a strong self-efficacy expectation. Indeed, only the behaviors that one believes they can be performed are started, and efforts are made to that end.

Whereas self-efficacy expectation is about one's perceptions of what they can do, outcome expectation is about expectancies of the outcomes of a behavior to be performed. While it is thought that self-efficacy expectation and outcome expectation are low or high in parallel with each other, there may be cases where one is lower or higher than the other. For instance, the individual may think that they can receive a high return for doing a task; however, they may not regard themselves as efficacious in that task. In an exact opposite case, the individual may regard themselves as efficacious in a given matter but may also have the negative outcome expectations that they will not be accepted or will be excluded by their social circle when they do the task, and therefore, may desist from the task (Lent, 2005).

In summary, outcome expectation is defined as individual's prediction about the probability of an outcome. On the other hand, self-efficacy expectation is about the question "Can I do a given task?". In this sense, outcome expectations refer to what can be the outcome of behaviors whereas efficacy expectation is about predicting the ability to achieve something (Sharf, 2014).

Outcome expectations can be specific to the outcomes of academic performance (e.g., I can have a career if I get good marks). Or, it can be about career choice and planning (e.g., I can make better career decisions if I can learn more about different fields of career). It is thought that outcome expectations, like efficacy expectations, are of critical importance for career interest and career choice (Betz \& Voyten, 1997). 


\section{Al Macrothink}

Bandura (1986) stated that there are a few different outcome expectations including physical, social and self-assessment. Career-related outcome expectations are personal beliefs that can be caused by individual's career decisions and behaviors. In the career decision-making process, which is multi-dimensional and complex, one can say that adolescents' beliefs about the outcomes of their career decisions and behaviors are important in the career development process.

Given the importance of high school years in regard to career development process, it can be argued that high school students' expectations of the outcomes of career-related behaviors need to be taken in consideration. Hence, this study aimed to examine career and academic outcome expectations of high school students by several demographic variables.

\section{Method}

\subsection{Research Model}

Aiming to examine career and academic outcome expectations of high school students by gender, type of school and grade level, this study was designed in the survey model. In this research model, surveys or similar question forms are utilized to obtain data on attitudes, behaviors, beliefs or views of participants in a sample or study group chosen from among the target population (Christensen, Johnson and Turner, 2014).

\subsection{Study Group}

The study group of the research was composed of 695 students attending different grade levels at high schools in city center of Niğde in the Central Anatolia Region of Turkey. Demographic data of the students who participated in the research are shown in Table 1.

Table 1. Demographic data of study group

\begin{tabular}{|c|c|c|c|}
\hline & & $\mathbf{N}$ & $\%$ \\
\hline \multirow{2}{*}{ Gender } & Female & 390 & 56 \\
\hline & Male & 305 & 44 \\
\hline \multirow{2}{*}{ Type of School } & Anatolian High School & 363 & 52 \\
\hline & Vocational High School & 332 & 48 \\
\hline \multirow{4}{*}{ Grade Level } & $9^{\text {th }}$ Grade & 192 & 27 \\
\hline & $10^{\text {th }}$ Grade & 158 & 23 \\
\hline & $11^{\text {th }}$ Grade & 158 & 23 \\
\hline & $12^{\text {th }}$ Grade & 158 & 27 \\
\hline
\end{tabular}

According to Table 1, 56\% (390) of the participants are female and $44 \%$ (305) are male. The 
participants were found to be attending Anatolian High Schools (52\%, 363 students) and Vocational High Schools (48\%, 332 students). Of the students, 27\% (192) were in the ninth grade, $23 \%$ (158) in the tenth grade, $23 \%$ (158) in the eleventh grade, and $23 \%$ (158) in the twelfth grade.

\subsection{Data Collection Tools}

\subsubsection{Career Outcome Expectations and Exploration Intentions}

Career Outcome Expectations and Exploration Intentions Scale was developed by Betz and Voyten (1997) to measure career outcome expectations, academic outcome expectations and exploration intentions. The scale is composed of 14 items and three subscales which are academic outcome expectations ( 5 items aimed to assess the beliefs regarding the relevance of educational performance to future career options and success), career outcome expectations (4 items defining outcome expectations regarding career decision making behaviors) and exploratory intentions (5 items that assess career exploration plans or intentions that are considered a goal). It used a 5-point rating scale between strongly disagree (1) and strongly agree (5) in the scale. Higher scores reflect expectations of more positive results. The internal consistency coefficients were reported to be .77 for academic outcome expectations, .79 for career outcome expectations, and .73 for exploratory expectations (Betz \& Voyten, 1997).

The scale was adapted into Turkish language by Büyükgöze-Kavas (2011). In the adaptation study, the study was applied to 303 undergraduates. The factor analysis showed Career Outcome Expectations and Exploratory Intentions Scale to have a factor structure consistent with the original scale. Accordingly, the scale is divided into three separate subscales of career outcome expectations, academic outcome expectations and exploratory intentions.

In this present study, academic (5 items) and career (4 items) outcome expectation subscales of the Career Outcome Expectations and Exploratory Intentions Scale were utilized. The internal consistency analysis performed for this study found the coefficients to be .78 for career outcome expectation and .79 for academic outcome expectation.

\subsubsection{Personal Information Form}

A personal information form developed by the researchers was used for collecting demographic data of the participants of gender, type of school, and grade level.

\subsection{Data Analysis}

SPSS 24.0 statistical software package was utilized for the data analysis. Differences between groups were analyzed with $t$ test and one-way variance techniques for the variables of gender, type of school and grade level.

\section{Results}

This section addresses the examination of findings achieved in the data analysis on high school students' career and academic outcome expectations by gender, type of school and grade level, respectively. 


\section{Macrothink}

Table 2. Examination of career outcome expectations by gender

\begin{tabular}{|l|l|l|l|l|l|l|}
\hline & Gender & $\mathbf{N}$ & $\overline{\mathbf{X}}$ & Sd & $\mathbf{t}$ & $\mathbf{p}$ \\
\hline \multirow{3}{*}{ Career Outcome Expectation } & Female & 390 & 17.22 & 3.02 & \multirow{3}{*}{3.98} & \multirow{2}{*}{$.000^{*}$} \\
\cline { 2 - 6 } & Male & 305 & 16.28 & 3.14 & & \\
\hline
\end{tabular}

Note. ${ }^{*} \mathrm{p}<.05$.

According to Table 2, girls' mean score of career outcome expectation $(\overline{\mathrm{X}}=17.22)$ was found to be higher than boys' mean score $(\overline{\mathrm{X}}=16.28)$. Results of the $t$ test performed for the significance of difference between the mean scores indicated a significant difference between the mean scores of career outcome expectation by gender $(t=3.98 ; \mathrm{p}<.05)$.

Table 3. Examination of academic outcome expectations by gender

\begin{tabular}{|l|l|l|l|l|l|l|}
\hline & Gender & $\mathbf{N}$ & $\overline{\mathbf{X}}$ & Sd & $\mathbf{t}$ & $\mathbf{p}$ \\
\hline \multirow{3}{*}{ Academic Outcome Expectation } & Female & 390 & 21.36 & 3.62 & \multirow{3}{*}{3.35} & \multirow{2}{*}{$.001^{*}$} \\
\cline { 2 - 7 } & Male & 305 & 20.41 & 3.79 & & \\
\hline
\end{tabular}

Note. ${ }^{*} \mathrm{p}<.05$.

As seen in Table 3, girls' mean score of academic outcome expectation $(\bar{X}=21.36)$ was found to be higher than boys' mean score $(\overline{\mathrm{X}}=20.41)$. Results of the $\mathrm{t}$ test performed for the significance of difference between the mean scores indicated a significant difference between the mean scores of academic outcome expectation by gender $(t=3.35 ; p<.05)$.

Table 4. Examination of career outcome expectations by type of school

\begin{tabular}{|l|l|l|l|l|l|l|}
\hline & Type of School & $\mathbf{N}$ & $\overline{\mathbf{X}}$ & Sd & $\mathbf{t}$ & $\mathbf{p}$ \\
\hline \multirow{3}{*}{ Career Outcome Expectation } & Anatolian High School & 363 & 17.50 & 2.41 & \multirow{3}{*}{6.13} & \multirow{2}{*}{$.000^{*}$} \\
\cline { 2 - 7 } & Vocational High School & 332 & 16.05 & 3.58 & & \\
\hline
\end{tabular}

Note. ${ }^{*} \mathrm{p}<.05$.

As for the data on type of school, Anatolian High School students' mean score of career outcome expectation $(\overline{\mathrm{X}}=17.50)$ was observed to be higher than Vocational High School students' mean score $(\bar{X}=16.05)$. Results of the t test performed for the significance of difference between mean scores of career outcome expectation for students of both school types indicated a significant difference $(t=6.13 ; \mathrm{p}<.05)$. 


\section{Macrothink}

Table 5. Examination of academic outcome expectations by type of school

\begin{tabular}{|l|l|l|l|l|l|l|}
\hline & Type of School & $\mathbf{N}$ & $\overline{\mathbf{X}}$ & Sd & $\mathbf{t}$ & $\mathbf{p}$ \\
\hline \multirow{2}{*}{ Academic Outcome Expectation } & Anatolian High School & 363 & 21.80 & 2.79 & \multirow{3}{*}{6.35} & \multirow{2}{*}{$.000^{*}$} \\
\cline { 2 - 7 } & Vocational High School & 332 & 20.01 & 4.35 & & \\
\hline
\end{tabular}

Note. ${ }^{*} \mathrm{p}<.05$.

As for the data on type of school, Anatolian High School students' mean score of academic outcome expectation $(\overline{\mathrm{X}}=21.80)$ was observed to be higher than Vocational High School students' mean score $(\bar{X}=20.01)$. Results of the t test performed for the significance of difference between mean scores of academic outcome expectation for students of both school types indicated a significant difference $(t=6.35 ; \mathrm{p}<.05)$.

Table 6. Descriptive statistics on career outcome expectations by grade level

\begin{tabular}{|l|l|l|l|}
\hline Grade Level & $\mathbf{N}$ & $\overline{\mathbf{X}}$ & Sd \\
\hline $9^{\text {th }}$ Grade & 192 & 17.64 & 2.58 \\
\hline $10^{\text {th }}$ Grade & 158 & 16.70 & 3.29 \\
\hline $11^{\text {th }}$ Grade & 158 & 16.37 & 3.18 \\
\hline $12^{\text {th }}$ Grade & 187 & 16.42 & 3.23 \\
\hline
\end{tabular}

It is seen in Table 6 that the ninth-grade students had the highest mean score of career outcome expectation $(\overline{\mathrm{X}}=17.64)$ among all grade levels. The ninth-grade students were followed by the tenth-grade $(\overline{\mathrm{X}}=16.70)$, twelfth-grade $(\overline{\mathrm{X}}=16.42)$ andl eleventh-grade $(\overline{\mathrm{X}}$ $=16.37$ ) students, respectively. The significance of difference between the grade levels in career outcome expectation scores was tested with one-way ANOVA.

Table 7. Results of ANOVA on career outcome expectations by grade levels

\begin{tabular}{|l|l|l|l|l|l|}
\hline Career Outcome Expectation & Sum of Squares & Sd & Mean of Squares & F & p \\
\hline Between Groups & 191.846 & 3 & 63.949 & & \\
\cline { 1 - 3 } Within Groups & 6514.462 & 691 & 9.428 & \multirow{3}{*}{6.78} & $.000^{*}$ \\
\cline { 1 - 4 } & 6706.308 & 694 & & & \\
\hline
\end{tabular}

Note. ${ }^{*} \mathrm{p}<.05$. 


\section{MInstitute ${ }^{\text {Macrothink }}$}

According to the results of one-way ANOVA on the significance of difference between mean scores of career outcome expectation by grade levels in Table 7, the mean scores were found to differ significantly by grade level $(\mathrm{F}=6.78 ; \mathrm{p}<.05)$. Conducted to find between which groups the difference was, the post-hoc test concluded that the ninth-grade students had higher career outcome expectation scores than the students in other grade levels (tenth, eleventh, and twelfth grades $)(\mathrm{p}<.05)$.

Table 8. Descriptive statistics on academic outcome expectations by grade level

\begin{tabular}{|l|l|l|l|}
\hline Grade Level & $\mathbf{N}$ & $\overline{\mathbf{X}}$ & Sd \\
\hline $9^{\text {th }}$ Grade & 192 & 22.10 & 3.11 \\
\hline $10^{\text {th }}$ Grade & 158 & 20.86 & 3.82 \\
\hline $11^{\text {th }}$ Grade & 158 & 20.53 & 3.69 \\
\hline $12^{\text {th }}$ Grade & 187 & 20.18 & 3.99 \\
\hline
\end{tabular}

As seen in Table 8, the ninth-grade students were found to have the highest mean score of academic outcome expectation $(\overline{\mathrm{X}}=22.10)$. The ninth-grade students were followed by the tenth-grade $(\overline{\mathrm{X}}=20.86)$, eleventh-grade $(\overline{\mathrm{X}}=20.53)$ and twelfth-grade $(\overline{\mathrm{X}}=20.18)$ students. The significance of difference between the mean scores was tested with one-way ANOVA.

Table 9. Results of ANOVA on Academic Outcome Expectations by Grade Levels

\begin{tabular}{|l|l|l|l|l|l|}
\hline Academic Outcome Expectation & Sum of Squares & Sd & Mean of Squares & F & p \\
\hline Between Groups & 393.491 & 3 & 131.164 & & \\
\cline { 1 - 4 } Within Groups & 9246.644 & 691 & 13.382 & \multirow{3}{*}{9.80} & $.000^{*}$ \\
\cline { 1 - 4 } Total & 9640.135 & 694 & & & \\
\hline
\end{tabular}

Note. ${ }^{*} \mathrm{p}<.05$.

According to Table 9, there was a significant difference between academic outcome expectation scores by grade levels $(\mathrm{F}=9.80 ; \mathrm{p}<.05)$. The post-hoc test conducted to find between which groups the difference was concluded that the ninth-grade students had higher mean scores of academic outcome expectation than the students in other grade levels (tenth, eleventh, and twelfth grades $)(\mathrm{p}<.05)$.

\section{Discussion}

The data of this present study conducted to examine career and academic outcome expectations of high school students were collected from 695 voluntary students attending different grade levels of high schools in city center of Niğde in the Central Anatolian Region 
of Turkey.

As argued by researchers who have investigated how social factors such as race, culture and gender affect career efficacy expectations and outcome expectations, such factors have an indirect impact on career interests, goals and behaviors (Lent, Brown, \& Hackett, 2002). In the analysis of the data obtained in this study, it was found that career and academic outcome expectations differed significantly by gender. As for mean scores of career and academic outcome expectations by gender, girls were found to have higher mean scores than boys.

Regarding the findings on grade level, the ninth-grade students were found to have higher mean scores of career and academic outcome expectation than the students in all other grade levels. The fact that the ninth-grade students just started the high school education is thought to be effective in their higher mean scores of outcome expectations.

As another finding of the study, there were significant differences in career and academic outcome expectations by grade levels. Accordingly, Anatolian High School students were found to have higher scores of career and academic outcome expectations than Vocational High School students.

In the current high school course schedules in Turkey (Ministry of National Education, 2018), it is observed that the guidance and orientation course is only available in ninth and twelfth grades. The research concluded significant differences in career and academic outcome expectation scores in favor of Anatolian High School students and ninth-grade students. The findings regarding low career and academic outcome expectation scores among vocational high school students and other grade level students are important in terms of showing that the dissemination of guidance and orientation course in all grade levels and school types can positively contribute to students' career development and expectations.

In Turkey, career outcome expectation (Büyükgöze-Kavas, 2011) and vocational outcome expectation (Işsk, 2013; Sarı, 2018; Sarı, Kabadayı, \& Şahin, 2017; Yılmaz, Dündar, \& Atli, 2020) have been investigated by limited number of studies. It is thought that the findings of this present study will contribute to the literature regarding outcome expectations related to career development process.

There are some limitations of this study which addressed career and academic outcome expectations in terms of certain demographic variables. The study method is one of those limitations. Designed with the quantitative method, this research was conducted in the survey model. Thus, it can be recommended to address other variables (vocational interest, vocational value, etc.) related to career development process and explore their relationships with outcome expectations and to conduct mixed-design studies that utillize qualitative and quantitative methods together in future studies on career outcome expectations.

\section{Acknowledgements}

This study is the revised and expanded version of the oral presentation presented at the V. International Congress on Education and Social Sciences held in Istanbul on 27-29 June 2019. 


\section{Macrothink}

\section{References}

Bandura, A. (1986). Social Foundations of Thought and Action: A Social Cognitive Theory. Englewood Cliffs, NJ: Prentice\&Hall.

Betz, N. E., \& Voyten, K. K. (1997). Efficacy and outcome expectations influence career exploration and decidedness. The Career Development Quarterly, 46(2), 179-189. https://doi.org/10.1002/j.2161-0045.1997.tb01004.x

Büyükgöze Kavas, A. (2011). Testing a model of career indecision among university students based on social cognitive career theory (Doctoral dissertation, Middle East Technical University, Ankara).

Christensen, L. B., Johnson, R. B., \& Turner, L. A. (2014). Research methods, design, and analysis (12th ed.). Pearson Education Limited.

Iş1k, E. (2013). Perceived Social Support and Locus of Control as the Predictors of Vocational Outcome Expectations. Educational Sciences: Theory \& Practice, 13(3), 1419-1430.

Lent, R. W. (2005). A Social Cognitive View of Career Development and Counseling. In S. D. Brown \& R. W. Lent (Eds.), Career Development And Counseling: Putting Theory And Research To Work (pp. 101-127). Hoboken, NJ: Wiley.

Lent, R. W., \& Brown, S. D. (1996). Social cognitive approach to career development: An overview. The Career Development Quarterly, 44(4), 310-321. https://doi.org/10.1002/ j.2161-0045.1996.tb00448.x

Lent, R. W., Brown, S. D., \& Hackett, G. (2002). Social cognitive career theory. In. D. Brown (Ed.), Career choice and development (pp. 255-311). John Wiley \& Sons.

Republic of Turkey Ministry of National Education. (2018). High School Weekly Course Schedule. Retrieved from http://ttkb.meb.gov.tr/meb_iys_dosyalar/2018_02/21173451_ort_ ogrtm_hdc_2018.pdf

Sarı, S. V. (2018). The role of perfectionısm in predictıng vocational outcome expectations. Journal of International Social Research, 11(55). http://dx.doi.org/10.17719/jisr.201855 37241

Sarı, S. V., Kabadayı, F., \& Şahin, M. (2017). Explanation of Vocational Outcome Expectation: Self-Transcendence, Self-Consciousness and Self-Control/Self-Management. Turkish Psychological Counseling and Guidance Journal, 7(48).

Sharf, R. S. (2014). Applying career development theory to counseling (6th ed.). Belmont, CA: Brooks/Cole.

Swanson, J. L., \& Fouad, N. A. (1999) Career theory and practice: Learming through cases. Thousand Oaks, CA: Sage.

Y1lmaz, I., Dündar, A., \& Atli, A. (2020). Expectation of Vocational Outcome as a Predictor of Life Satisfaction of University Students. Inonu University Journal of the Graduate School 


\section{Macrothink}

of Education, 7(13), 68-77. https://doi.org/10.29129/inujgse.640817

\section{Copyright Disclaimer}

Copyright for this article is retained by the author(s), with first publication rights granted to the journal.

This is an open-access article distributed under the terms and conditions of the Creative Commons Attribution license (http://creativecommons.org/licenses/by/3.0/). 